ISSN 2078-6441. Вісник Львівського університету. Серія географічна. 2014. Випуск 47. С. 18-29. Visnyk of the Lviv University. Series Geography. 2014. Issue 47. P. 18-29.

$551.8+624.131 .1$

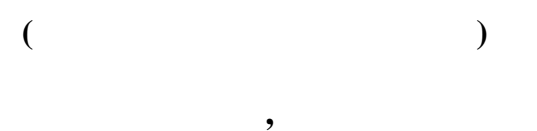

ьвівський н ціон льний університет імені в н вул. . орошенк, 41, 79000, м. ввів, кр їн

озріз ояничі-опорний - один із н йповніших, н йвідоміших і н йліпше вивчених розрізів перигляці льної лесово-грунтової серії олино- оділля, у якому предст влен м йже повн історія формув ння порід з ост нні 600 тис. років. г льн потужність лесово-грунтової серії тут ст новить близько $25 \mathrm{M}$. е стр тотип сок льського викопного грунту. ут уперше для олино- оділля виділено псевдоморфози по полігон льно-жильних льод х і обгрунтов но с мостійність бояницького п леокріогенного ет пу - одного з н йд вніших у плейстоцені. озріз ояничі вивчено з використ нням пр ктично усіх методів досліджень, які з стосовують для дослідження плейстоценових відкл дів (зокрем, мікроморфологічного, п леокріогенного, п леом гнітного, інженерно-геологічного, п леонтологічних, бсолютного д тув ння відкл дів т ін.). ведено дет льний опис розрізу, т кож результ ти інженерно-геологічного вивчення порід усіх виділених лесових і п леогрунтових горизонтів. 'ясов но індивіду льність вл стивостей виділених стр тигр фічних горизонтів і їхню $з$ лежність від п леогеогр фічних умов ос дон гром дження.

лючові слов : леси, похов ні грунти, п леогеогр фічні умови, п леокріогенез, інженерногеологічні вл стивості, прос дочність, олинськ височин .

озріз ояничі-опорний розт шов ний н південно-з хідній околиці с. ояничі ок льського р-ну ьвівської обл. е великий мех нізов ний к р'єр цегельночерепичної сировини для сок льських цегельних з водів. гідно зі схемою геоморфологічного р йонув ння . ися, територія досліджень н лежить до геоморфологічного р йону ок льсько- орчинської п смової височини підобл сті олинської височини [7].

ояничі - один з н йповніших, н йвідоміших і н йліпше вивчених розрізів перигляці льної лесово-грунтової серії не тільки олино- оділля, й вропи. ут розкрит нижньоплейстоценов (сян 2, окськ ) морен - в жливий стр тигр фічний репер, тут різними метод ми прод тов но всі стр тигр фічні горизонти, тут є стр тотип сок льського викопного грунту, тут обгрунтов но с мостійне зн чення бояницького п леокріогенного ет пу середнього плейстоцену і 6 г то іншого $[1,2,6,9]$. ому дет льн інженерно-геологічн х р ктеристик порід лесово-грунтової серії розрізу ояничі м тиме в жливе зн чення для всебічного вивчення розрізу, т кож для використ ння в пр ктиці інженерно-геологічних досліджень [3].

ведемо дет льний опис порід розрізу ояничі-опорний (див. рисунок).

(C) огуцький ., олошин ., 2014 


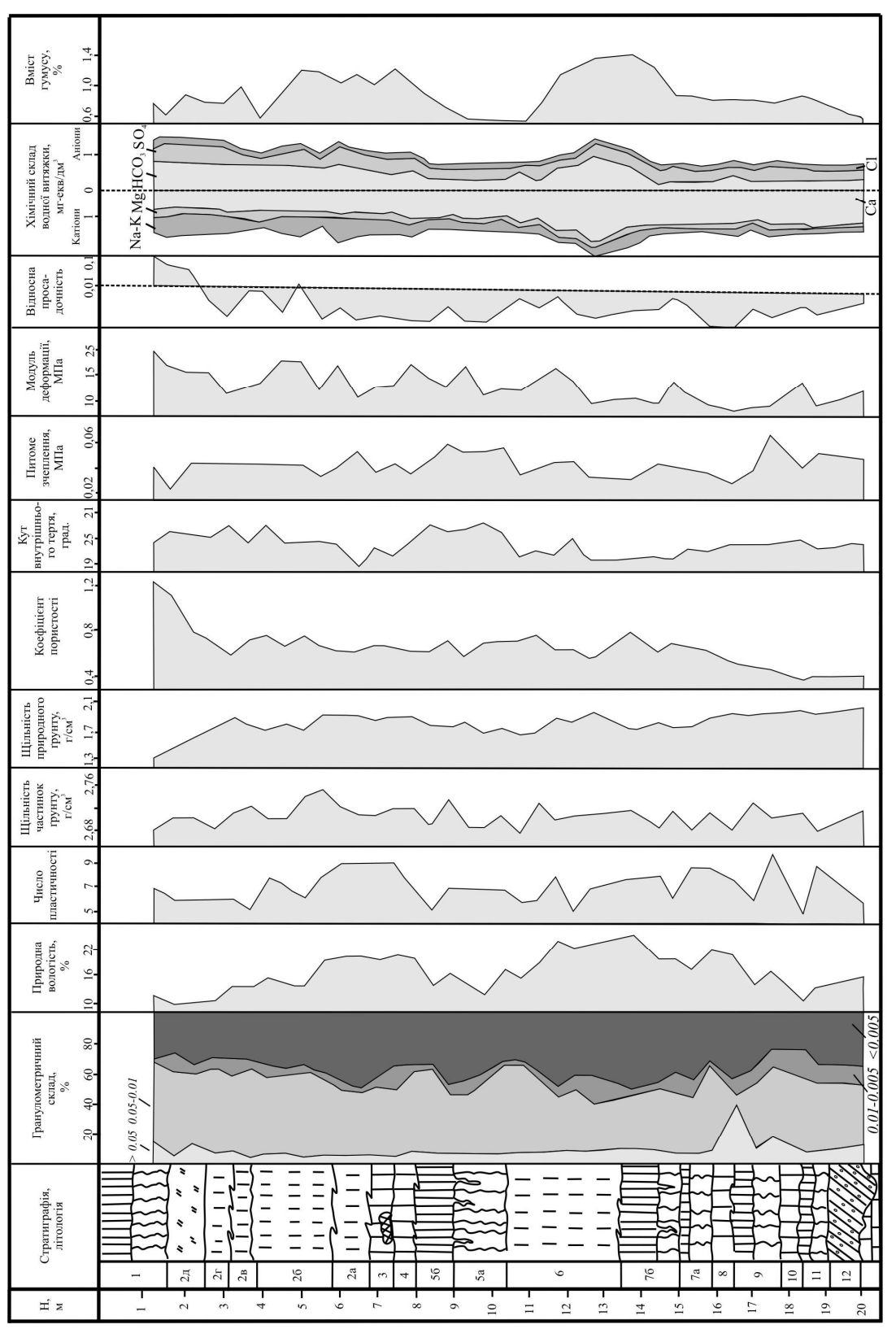

ㄴ:

8 : :

.

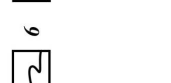

S

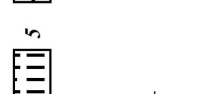

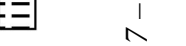

ㅂ.

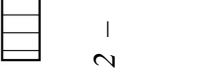

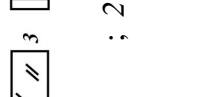

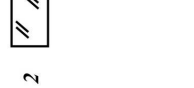

闩客在当

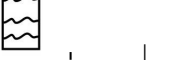

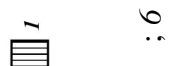

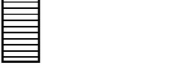

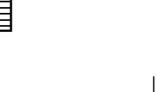

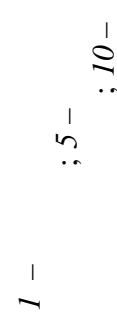


уч сний грунт, чорнозем (1) 1 .

либин , м

умусовий ( ) горизонт м є потужність 0,5 м. кл дений супіск ми темно-сірими, м кропористими до к вернозних, з корінням рослин, інтенсивно біогенно переробленими (кротовини до $10 \mathrm{~cm}$, червоточини до 2 см у ді метрі). ерехід поступовий.

ерехідний ( / ) горизонт м є потужність 0,4 м. кл дений супіск ми легкими, сірими, жовтув то-сірими, к рбон тними, які інтенсивно біогенно перероблені. ерехід поступовий.

люві льний ( $к$ рбон., кротов.) горизонт потужністю 0,8 м. кл дений супіск ми жовтув то-бурими, які інтенсивно з кип ють з соляною кислотою, м кропористими, тріщинув тими, біогенно переробленими (червоточини до 2,0 cm т кротовини до $10,0 \mathrm{~cm}$ ді метром).

н повнюв чі червоточин і кротовин перев ж ють супіски гумусного горизонту. ижній конт кт ясний, з зміною кольору. ін фіксов ний т кож скупченням к рбон тних конкрецій-дутиків до 5,0 см ді метром.

ерхній горизонт верхньоплейстоценових лесів (2).

орфологічно неоднорідний і розділений н низку підгоризонтів (зверху вниз).

p силівський підгоризонт (2д) є похов ним діяльним ш ром фі0,0-1,7 н льноплейстоценового п леокріогенного ет пу. кл дений супіск ми голубув то-сірими, легкими, щільними, м кропористими, просякнутими 3, 3 великою кількістю дутиків до 3,0 см у ді метрі. ш рі нем ло плям оз лізнення до 5,0 см у ді метрі і новоутворень типу кілець ізег нг , трубч стих, орієнтов них вертик льно. соляною кислотою супіски інтенсивно вз ємодіють. ш рі виявлено суч сні кротовини до 7,0-10,0 см у ді метрі. ижній конт кт ясний. ін фіксов ний зміною кольору і скл днохвилястими смуг ми бурого оз лізнення.

ерхній підгоризонт верхнього горизонту верхньоплейстоценових лесів (2г). кл дений супіск ми п левими, м кропористими, однорідними. они інтенсивно з кип ють з соляною кислотою. ш рі велик кількість псевдоміцелію, з фіксов но поодинокі плями оз лізнення. ижній конт кт хвилястий, виділений смуг ми бурого оз лізнення і сизого оглеєння.

івненський підгоризонт (2в) скл дений супіск ми м кропористими, щільними, плік тивно деформов ними, з псевдоміцелієм, сірими, інколи з голубув тим відтінком. о периметру лінз і грив простежується інтенсивніше оглеєння. ш рі нем ло щільних к рбон тних дутиків, т кож $з$ лізисто-м нг нових прим зок. ижній конт кт поступовий.

ижній підгоризонт верхнього горизонту верхньоплейстоценових лесів (2б). еси п леві, ділянк ми сірі, м кропористі, щільні, неяснош рув ті, що виділено нерегулярними смуг ми бурого оз лізнення.

1 ут і д лі номер горизонту чи підгоризонту відповід є стр тигр фічній шк лі $[1,5]$. 
нтенсивно вз ємодіють 3 соляною кислотою. ерехід 3 появою плік тивно деформов них лінзочок дубнівських суглинків.

ідгоризонт н ддубнівської соліфлюкцї̈ (2 ) чітко (з літологічними особливостями, морфологією i 3 кип нням 3 соляною кислотою) розділений н дві ч стини. верхніх $0,5 \mathrm{M}$ перев ж ють п леві к рбон тні леси з поодинокими лінзочк ми і грив ми в жких суглинків дубнівського грунту. нижніх 0,3 м домінують уже лінзи і гриви дубнівських суглинків. р плік тивно деформов ний, породи повсюди 3 кип ють з соляною кислотою. ньому 6 г то видовжених дутиків до 10,0 см довжиною. о периметр х лінз і грив смуги бурого оз лізнення. отужність грив зрідк перевищує 0,1 м.

убнівський грунт (3) гомогенно-глейовий. кл дений суглинк ми $6,3-6,8( \pm 0,1)$ голубув то-сірими (сизими), щільними, оз лізненими, однорідними, які в основній м сі не вз ємодіють з соляною кислотою. фіксов но плями i смуги бурого оз лізнення, т кож новоутворення типу кілець ізег нг . дубнівському грунті тр пляються лінзи і гнізд дуже пухких суглинків, переповнених трубч стими (1,0-3,0 мм у ді метрі) i пилув тими к рбон т ми. ижній конт кт скл днохвилястий, з фіксов ний смуг ми бурого оз лізнення потужністю до 3,0 см, що переходять в ортз нди.

ижній горизонт верхньоплейстоценових лесів (4) скЛ дений суглинк ми. они к рбон тні, жовтув то-коричневі (до сірих) у нижній половині ш ру (підгоризонт 4 ), червонув то-коричневі - у верхній (підгоризонт 4б). ілянк ми суглинки сизі вн слідок оглеєння. они щільні, одн к м кропористі, 3 кип ють 3 соляною кислотою, містять велику кількість з лізисто-м нг нових прим зок, плям оз лізнення і оглеєння. ш рі інколи н всю потужність (ч стіше лише в його нижній ч стині) простежується неповносітч ст посткріогенн текстур (висот сітки - 0,5 см, ширин - 1,0-1,5 см). о текстурних окремостях чіткі плівки бурого оз лізнення. нижній половині ш ру тр пляються лінзи і гриви гумусов них суглинків горизонту горохівського викопного грунтового комплексу, потужністю 0,1 м, зрідк більше.

орохівський викопний грунтовий комплекс (5). П динний в рінт (з потужним елюві льним ( ) горизонтом). $є$ добре диференційов ний профіль.

умусовий ( ) горизонт потужністю 0,6 м скл дений суглинк ми темно-сірими з червонув тим відтінком, щільними, безструктурними, які в3 ємодіють з соляною кислотою. верхній ч стині суглинки гумусового горизонту м ють добре вир жену неповносітч сту посткріогенну текстуру (висот сітки - до 0,5 см, ширин - 1,0-1,5 см) з інтенсивною просякнутістю гідрооксид ми з ліз по текстурних окремостях. о нижньому конт кту суглинків з посткріогенною текстурою інколи простежуються ортз нди до 1,0 см потужністю. нижній ч стині горизонту тр пляються ділянки з білястою підзолистою присипкою. $\mathrm{p}$ порушений соліфлюкційними процес ми, у ньому нем ло з лізисто-м нг нових

$7,8-9,6$

(i більше) 
прим зок і конкрецій до 3,0 мм у ді метрі, головно чорних. ерехід ясний, $з$ кольором, інколи язикув тий (з косм ми).

люві льний ( ) горизонт м є потужність 0,15-0,20 м. е біляст

“пудр ”-присипк 3 коричневим відтінком, безк рбон тн, суцільно н повнен чорними з лізисто-м нг новими конкреціями до 2,0 мм і більше у ді метрі.

люві льний ( ) горизонт м є потужність 1,0-1,5 м і морфологічно розділений н три підгоризонти.

ідгоризонт ' скл дений супіск ми щільними, комірч стими (ді метр комірок - до 1 см), коричневими, 3 білястою підзолистою присипкою. отужність підгоризонту - 0,3 м.

ідгоризонт ” потужністю 0,4 м скл дений ор нжевими супіск ми, комірч стими, дуже щільними, безк рбон тними, що просякнуті гідрооксид ми з ліз .

ідгоризонт "” потужністю 0,7 м відрізняється від підгоризонту ', зн чно меншою просякнутістю гідрооксид ми з ліз , т кож помітно меншою щільністю. ерехід ясний.

ерхній горизонт середньоплейстоценових лесів (6) морфологічно й генетично неоднорідний і розділений н низку підгоризонтів.

зерні (?) суглинки (6e) з гр нулометричним скл дом близькі до

$9,6-12,6$

$9,6-10,8$ тонкозернистих пісків. ерх горизонту явно ш рув тий з вдяки тонким (1,0-3,0 мм) піщ ним (пудр ) прош рк м. ороди інтенсивно оз лізнені, оглеєні. о всьому ш ру п тьоки гідрооксидів бурого оз лізнення. вно відчутний вплив процесів горохівського грунтоутворення. олір порід зеленкув то-жовтий, інколи бурий ун слідок оз лізнення і сизий ун слідок оглеєння. ижній конт кт хвилястий, ясний, швидше 3 все, соліфлюкційно порушений.

елюві льно-соліфлюкційн $n$ чк (6д) скл ден суглинк ми, у нижній половині ш ру в жчими, ніж у верхній. углинки голубув тоcipi, інколи сизі, зі скл днохвилястими смуг ми бурого оз лізнення потужністю до 1,0 см і більше. основній м сі суглинки з соляною кислотою не вз ємодіють, з кип ють лише н ділянк $\mathrm{x}$ скупчення вторинних к рбон тів. ш рі б г то плям гумусу до 5,0 см у ді метрі. ід верхнього конт кту суглинків через кожні 0,7-1,0 м відходять гриви висотою до 0,4 м, сл бко н хилені 3 п леорельєфом. о периметру грив простежуються оглеєння і плівки бурого оз лізнення. ш рі б г то вторинних к рбон тів, включ ючи білі к рбон тні н тьоки по тріщин х. ерехід ясний, з кольором т зменшенням оз лізнення.

лейовий ембріон льний грунт - тернопільський підгоризонт (6в). енетичний профіль грунту м є т ку будову.

умусовий ( ) горизонт потужністю 0,2 м скл дений в жкими суглинк ми, в'язко-пл стичними, однорідними, із з лізисто-м нг новими прим зк ми. соляною кислотою суглинки не вз ємодіють.

люві льний ( ) горизонт потужністю 0,2 м, скл дений суглинк ми червонув то-коричневими, в'язко-пл стичними, однорідними, які сл бко $з$ кип ють $з$ соляною кислотою. 
дкоршівськ делюві льно-соліфлюкційн $n$ чк (6 ). верхній

$11,8-12,6$ ч стині перев ж ють суглинки голубув то-сірі, плік тивно деформов ні, що виділено смуг ми бурого оз лізнення, з великою кількістю 3 лізисто-м нг нових новоутворень (прим зок). нижній ч стині ш ру чіткі гриви гумусов них суглинків (потужністю до 10,0 см) коршівського грунту, що з ляг є нижче. окремих з чистк х простежуються порівняно однорідні в жкі суглинки без явних озн к соліфлюкційної деформов ності. е м теринськ пород тернопільського грунтоутворення (підгоризонту 6б).

оршівський викопний грунтовий комплекс (7).

пис змішено до іншого вибою, який розт шов ний н стінці східної експозиції, з 100 м н південний з хід від опис ної вище. оршівський комплекс скл дений двом грунт ми, які відповід ють двом фз м грунтоутворення коршівського ч су.

рунт другої ф зи грунтоутворення (верхній, чорноземоподібний - 7б).

умусовий ( ) горизонт потужністю 1,3 м скл дений суглинк ми темно-сірими, зверху світлішими (до сірих), знизу - з жовтув то-бурим відтінком. углинки м кропористі, безструктурні, не вз ємодіють з соляною кислотою, інтенсивно біогенно перероблені. ш рі нем ло кротовин (до 10 см) і червоточин (до 2 см), 3 повнених м тері лом горизонту . Г то з лізисто-м нг нових прим зок і конкрецій до 3,0 мм у ді метрі. онт кт язикув тий (косм тий). зики-косми глибиною до 1,0 м і більше регулярно (через 1,3 м) відходять від гумусового горизонту у підстильні ш ри.

люві льний ( ) горизонт потужністю 0,6 м скл дений порівняно однорідними жовтими суглинк ми з інтенсивною біогенною переробленістю (б г то червоточин - “леоп рдовість”, кротовин). ервоточини і кротовини з повнені м тері лом горизонту . ш рі т кож б г то 3 лізисто-м нг нових прим зок і конкрецій. ерехід ясний, фіксов ний зміною кольору, смуг ми оглеєння й оз лізнення.

рунт першої ф зи коршівського грунтоутворення (нижній - 7 ).

умусовий ( ) горизонт потужністю 0,3 м предст влений щільними, одн к м кропористими суглинк ми, однорідними, переповненими 3 лізисто-м нг новими прим зк ми і конкреціями до 3,0 мм у ді метрі. углинки безструктурні. ерехід 3 зміною кольору, щільності й структури порід, з г лом ясний.

люві льний ( ) горизонт потужністю 0,9 м предст влений червонув то-жовтими, щільними, оструктуреними (грудкув тими) суглинк ми, 3 плям ми бурого оз лізнення і сизого оглеєння до 10,0 см у ді метрі, т кож поодинокими з лізисто-м нг новими прим зк ми. ерехід ясний, 3 зміною щільності, структури порід, появою смуг бурого оз лізнення.

ижній горизонт середньоплейстоценових лесів (8) морфологічно неоднорідний. ерхні 0,5 м скл дені суглинк ми щільними, порівняно однорідними, жовтув то-сірими, лесоподібними. е м теринськ пород коршівського грунтоутворення (підгоризонт 8б). ижні 0,6 м ш ру - тонкош рув т п чК, як скл д ється з супісків оглеєних, 
сизих, що не вз ємодіють із соляною кислотою, оз лізнених, із з лізисто-м нг новими новоутвореннями, і пісків дрібно- й тонкозернистих, білястих (пудр ), які, можливо, є м тері лом горизонту , що з ляг є нижче від луцького викопного грунту. отужність супіщ них прош рків ст новить м ксим льно 10 см, пісків - 1-2 см. о ш рув тості простежуються чіткі смуги оз лізнення. п чці нем ло новоутворень типу кілець ізег нг . ижній конт кт ясний. обре видно, що білястий м тері л проник є в горизонт луцького грунту.

пис ний підгоризонт корелює, швидше 3 все, 3 н длуцькою делюві льно-соліфлюкційною $n$ чкою (8), досить повно предст вленою у розрізі оршів $[4,8]$. езпосередньо н д цим горизонтом у розрізі оршів з ляг ють голубув то-сірі суглинки з добре вир женою крупносітч стою текстурою (висот сітки - близько 5 см, ширин $-10-15$ см).

уцький викопний грунт (9) предст влений лише ілюві льним ( ) горизонтом.

люві льний ( ) горизонт луцького грунту скл дений суглинк ми щільними, червонув то-коричневими, оструктуреними, грудкув тими, оз лізненими, з численними з лізисто-м нг новими новоутвореннями. углинки порушені соліфлюкцією, н йінтенсивніше у верхній ч стині ш ру. ш рі б г то плям оглеєння й оз лізнення до 10,0 см у ді метрі. простяг нням у горизонті тр пляються ділянки, менше порушені соліфлюкційними процес ми.

ерхній горизонт нижньоплейстоценових лесів (10) скл дений суглинк ми - м теринською породою грунтоутворення луцького віку. они порівняно однорідні світло-жовті, з плям ми оглеєння і поодинокими гнізд ми піску до 20 см у ді метрі.

ок льський викопний грунт (11) розвинутий Н морені й м Є чіткий генетичний профіль.

умусовий ( ) горизонт потужністю 0,2 м скл дений суглинк ми інтенсивно соліфлюкційно порушеними, сірими, глейовими, ун слідок чого вони м ють голубув тий відтінок.

люві льний ( ) горизонт потужністю 0,2 м скл дений червонув токоричневими опідзоленими суглинк ми, щільними, серед яких інколи тр пляються включення ул мкового м тері лу.

орен (сян 2, окськ) (12). олір верхньої ч стини морени черво-

$16,8-17,6$

$17,6-18,0$

$18,0-18,4$ нув то-бурий, ближче до підошви - зеленкув то-сірий. орен суглинист , піщ нист, містить гнізд і тріщинні (по тріщин х) включення різнозернистих бурих пісків до 0,20-0,30 м потужністю. ключення крупноул мкового (гр війного, г лечникового, в лунного т ін.) м тері лу простежуються по всьому ш ру, н йбільш кількість м тері лу тяжіє до піщ них ділянок морени. скл ді включень - кремінь, кв рц, кв рцити, гнейси, різної зернистості т ступеня звітрілості гр ніти, з лишки ф уни (белемніти т ін.) тощо. л мковий м тері л різної обк т ності, ді метр включень - до 0,4 м і більше. ксим льні розміри в лунів перевищують 1,0 м у ді метрі. 
ижній горизонт нижньоплейстоценових лесів. горизонті $19,7-21,4$ можн виділити низку ш рів різного гр нулометричного скл ду.

іски бурі кв рцові, дрібнозернисті, ш рув тість лінзоподібнохвиляст . о нижньому конт кту потужн (пон д 3,0 см) смуг бурого оз лізнення.

упіски п леві, у нижній ч стині сірі, ш рув ті, з тонкими (близько 1,0 см) піщ ними прош рк ми.

іски білі, сірі, косош рув ті, різнозернисті. тонких (до 5,0-7,0 см) прош рк х і лінз х вони грубозернисті з включеннями кв рцу, кременю і крист лічних порід тощо до 3,0 см у поперечнику.

линисті піски і легкі супіски коричневого кольору, у нижній ч стині 3 включеннями крейди (у тому числі добре обк т ними), кв рцу, кв рцитів, кременів, крист лічного м тері лу тощо до 20,0 см у ді метрі. Г то крист лічних включень сильно звітрілі (з зн ли впливу звітрюв ння). ляг ють глинисті піски н нерівній поверхні крейди.

глибини 21,4 м 3 ляг ють верхньокрейдові мергелі. хня поверхня дуже нерівн , що зумовило зн чний вплив н збереження і потужності морени й підморенних пісків.

ля вивчення інженерно-геологічних вл стивостей грунтів ${ }^{2}$ опорного розрізу ояничі $з$ основних лесових, п леогрунтових т п леокріогенних горизонтів відібр но проби порід непорушеної структури (моноліти) т визн чено їхній скл д і фізикомех нічні вл стивості. езульт ти л бор торних досліджень грунтів пок 3 но н рисунку. к б чимо, бсолютні зн чення пок зників окремих горизонтів змінюються у широких ді п зон х.

рунти верхнього горизонту верхньоплейстоценових лесів м ють типовий для лесів гр нулометричний скл д. ередній вміст піщ ної фр кції грунтів горизонту ст новить $6 \%$, пилув тої - 60, глинистої $(<0,001$ мм) - $21 \%$. томість гр нулометричний скл д окремих підгоризонтів суттєво відрізняється. прикл д, вміст пилув тих ч стинок змінюється від 70 до $47 \%$. рім того, простежується поступове зменшення кількості цих ч стинок з глибиною.

підгоризонті н ддубнівської соліфлюкційної п чки їхній вміст ст новить $47 \%$. ороди дубнівського викопного грунту порівняно з верхнім горизонтом верхньоплейстоценових лесів уміщують зн чно менше піску (3\%), пилу (52), одн к дещо більше глинистих ч стинок $(25 \%)$. томість у нижньому горизонті верхньоплейстоценових лесів знову з фіксов но зрост ння вмісту піщ них (4\%) і пилув тих (59) фр кцій т зменшення глинистих (19\%).

ля горохівського викопного грунтового комплексу х р ктерне зменшення вмісту пилу (52 \%) т зрост ння кількості глини (25\%).

р нулометричний скл д верхніх горизонтів середньо- т нижньоплейстоценових лесів пр ктично не відрізняється від скл ду верхнього горизонту верхньоплейстоценових лесів. міст піску у другому пересічно ст новить $6 \%$, пилу - 59, глини - $22 \%$.

нижньому горизонті середньоплейстоценових лесів простежується дещо нижчий

2 інженерній геології під грунт ми розуміють усі породи, які є середовищем бо основою споруд. 
вміст пилу (53\%) т підвищений вміст глини (29\%). ідгоризонти соліфлюкції т оглеєння, які входять до скл ду н зв них горизонтів, т кож м ють підвищену глинистість.

рунти коршівського викопного грунтового комплексу і луцького викопного грунту 3 гр нулометричним скл дом близькі до горохівського викопного грунтового комплексу. они пересічно вміщують 6-13\% піску, 46-51 - пилу і 25-27 \% глини.

ок льський викопний грунт, н відміну від інших викопних грунтів, м є більший вміст пилу (55\%) т менше глинистих ч стинок (19\%).

гр нулометричному скл ді лесової товщі досить добре простежується певн 3 кономірність. он виявляється у більшій пилув тості й меншій глинистості лесових горизонтів, і н вп ки, у меншій пилув тості т більшій глинистості викопних грунтів, викопних грунтових комплексів т соліфлюкційних горизонтів.

бсолютні зн чення природної вологості грунтів опорного розрізу ояничі змінюються від 10 до $24 \%$. грунт х верхнього горизонту верхньоплейстоценових лесів вони колив ються від 10 до $15 \%$, досяг ючи у н ддубнівській соліфлюкційній п чці 19-20\%. ижче, у дубнівському викопному грунті, нижньому горизонті верхньоплейстоценових лесів бсолютні зн чення природної вологості $€$ м йже ст лими і т кож ст новлять 19-20\%. орохівський викопний грунтовий комплекс м $є$ дещо нижчу (14-19\%) вологість порід.

верхньому горизонті середньоплейстоценових лесів вологість зменшується до 15-17\%. нижній ч стині цього ш ру (н дкоршівськ соліфлюкційн п чк ) вон зрост є до $18 \%$. грунт х коршівського викопного грунтового комплексу, луцького викопного грунту і нижнього горизонту середньоплейстоценових лесів вологість ст новить 22-24\%. д луцьким викопним грунтом (н длуцьк соліфлюкційн п чк ) вологість - близько $23 \%$. ок льський викопний грунт м є вологість 11-14\%. нижньому горизонті нижньоплейстоценових лесів вологість зрост є до $15 \%$.

л стичність грунтів лесово-грунтової товщі змінюється від 4 до 10 і тісно корелює з вмістом глини в окремих стр тигр фічних горизонт х. есові горизонти т підгоризонти м ють низькі зн чення числ пл стичності, які змінюються від 4 до 8. н ддубнівській соліфлюкційній п чці, дубнівському грунті т нижньому горизонті верхньоплейстоценових лесів вон зрост $є$ до 9. рунти горохівського т коршівського викопних грунтових комплексів м ють число пл стичності, що змінюється від 5 до 7.

ілюві льних горизонт х луцького т сок льського викопних грунтів воно досяг $€ 10$. ільність ч стинок грунту досліджув ної товщі змінюється у незн чних меж х - від

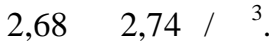

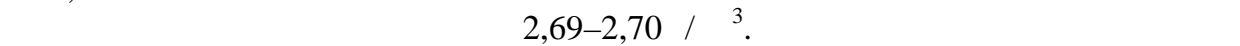

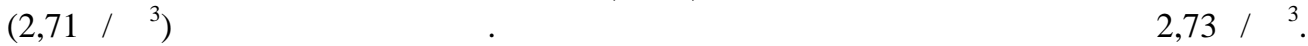
ільність природного грунту змінюється в широкому ді п зоні - від 1,35 до $2,13 г / \mathrm{cm}^{3}$. он $є$ суттєво різною для різновікових лесових, п леогрунтових т п леокріогенних горизонтів. йнижчі пок зники, які змінюються від 1,35 до 1,83 г/см ${ }^{3}$, прит м нні м ловологим, пухким грунт м верхніх горизонтів верхньо- т середньоплейстоценових лесів. н чно вищі зн чення щільності $(1,94-1,96$ г/см³ $)$ х р ктерні для нижніх горизонтів лесів верхнього т середнього плейстоцену.

ільність грунтів горохівського викопного грунтового комплексу зн чно нижч ,

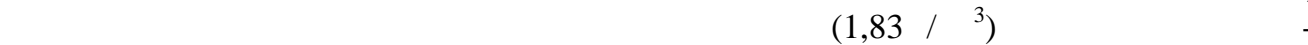

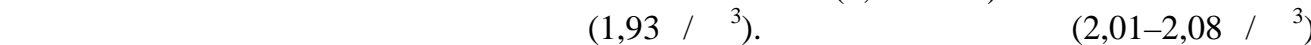
м ють луцький і сок льський викопні грунти. ксим льне бсолютне зн чення 
щільності $(2,13$ г/см³ $)$ з фіксов но у нижньому горизонті нижньоплейстоценових лесів, які з ляг ють н окській морені. ільність грунтів соліфлюкційних горизонтів

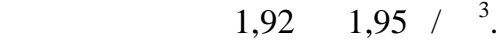

н чення коефіцієнт пористості тісно корелюють з пок зником щільності і т кож змінюються в широких меж х. они досить добре відобр ж ють мікростр тигр фію лесово-грунтової товщі. еси верхніх горизонтів верхнього т середнього плейстоцену, які формув лися у сухих холодних умов х, м ють н йвищий ступінь недоущільнення $\mathrm{i}$, відповідно, н йвищі коефіцієнти пористості $(0,70-1,22)$. оефіцієнти пористості нижніх горизонтів верхнього і середнього плейстоцену не перевищують 0,700. рунти горохівського і коршівського викопних грунтових комплексів м ють коефіцієнти пористості 0,688 т 0,720, відповідно. оефіцієнти пористості луцького т сок льського викопних грунтів є н йнижчими і ст новлять 0,566 т 0,474 .

ок зники міцності (кут внутрішнього тертя і питоме зчеплення) з г лом досить високі. ерхні лесові горизонти верхнього т середнього плейстоцену м ють досить високі кути внутрішнього тертя $\left(26^{\circ}\right)$ і питомого зчеплення $(0,04)$ ). більш глинистих нижніх горизонт х лесів верхнього т середнього плейстоцену кут внутрішнього тертя дещо нижчий $\left(23^{\circ}\right)$, питоме зчеплення вище $(0,05)$ ля грунтів горохівського викопного грунтового комплексу, луцького т сок льського викопних грунтів х р ктерні високі кути внутрішнього тертя (26-29) і питоме зчеплення $(0,05-$ 0,06 ). рунти коршівського викопного грунтового комплексу і соліфлюкційні горизонти м ють зн чно нижчий кут внутрішнього тертя $\left(22-23^{\circ}\right)$ і близьке до попередніх грунтів питоме зчеплення $(0,046)$ ).

одуль $з$ г льної деформ ції, визн чений 3 природної вологості, змінюється від 8 до 35 . і п зон колив нь середніх зн чень цього пок зник по окремих горизонт х зн чно менший. йбільший модуль деформ ції (21 ) прит м нний м ловологим грунт м верхнього горизонту верхньоплейстоценових лесів. ля викопних грунтів і грунтових комплексів він змінюється від 13 до 18 . йменше зн чення (9 ) з фіксов но в грунт х нижнього горизонту середньоплейстоценових лесів.

рос дочність грунтів 3 дод ткового (0,3 ) тиску виявляється фр гмент рно. он прит м нн головно н йбільш пухким, м ловологим лес м верхнього підгоризонту верхньоплейстоценових лесів т верхній ч стині нижнього підгоризонту верхньоплейстоценових лесів. бсолютною величиною цей пок зник змінюється від 0,014 до 0,114. езн чні коефіцієнти прос дочності, що не перевищують гр ничного зн чення $(0,01)$, м ють гумусові горизонти викопних грунтів другої т першої ф з коршівського грунтоутворення. ільні т вологі грунти горохівського, луцького т сок льського викопних грунтів, т кож н йбільш щільні й вологі лесові горизонти, підгоризонти оглеєння і соліфлюкції є непрос дочними.

д ними вивчення водної витяжки лесово-грунтов серія пр ктично відмит від легкорозчинних солей. одноч с н фоні з г льного низького вмісту простежується тенденція поступового зменшення їхньої кількості з глибиною. грунт х коршівського викопного грунтового комплексу, який відігр є роль геохімічного б р’єр , $з$ фіксов но суттєве зрост ння вмісту легкорозчинних солей. глибиною їхня кількість знову зменшується.

міст гумусу у лесово-грунтовій товщі тісно пов'яз ний з їі мікростр тигр фією.

йвищі його зн чення (до 1,6 \%) з фіксов но у коршівському викопному грунтовому комплексі. горохівському викопному грунтовому комплексі, луцькому т сок льсь- 
кому викопних грунт х його вміст не перевищує 1,0\%. умус у лесових горизонт х тр пляється у вигляді окремих плям і невеликих скупчень.

н ліз розподілу пок зників скл ду і вл стивостей лесових, п леогрунтових і п леокріогенних горизонтів свідчить про їхню суттєву відмінність, зумовлену особливостями п леогеогр фічних умов їхнього формув ння т ді генетичного перетворення. окремими пок зник ми простежується чітко вир жен циклічність, що д ло змогу створити інженерно-стр тигр фічну схему лесово-грунтової серії олино- оділля [3].

1. огуцкий . нтропогеновые покровные отложения олыно- одолии / . огуцкий // нтропогеновые отложения кр ины. - иев : ук. думк , 1986. - . 121-132.

2. огуцкий . сновные п леокриогенные эт пы плейстоцен юго-з п д осточновропейской пл тформы / . огуцкий // етвертичный период : методы исследов ния, стр тигр фия и экология. ез. V сесоюз. совещ. - ллинн, 1990. - . 1. . 65-66.

3. огуцкий . икличность лессовой толщи юго-з п д усской пл тформы и инженерн я стр тигр фия / . огуцкий, · олошин / еория цикличности лессов в пр ктике инженерно-геологических изыск ний. - . . : ук , 1985. - . 111-120.

4. огуцький . нженерно-геологічн х р ктеристик порід лесово-грунтової серії опорного розрізу оршів ( олинськ височин ) / . огуцький, . олошин // icник ьвів. ун-ту. ер. геогр. - 2013. - ип. 42. - . 11-21.

5. огуцький . . есовий покрив олинської височини / . . огуцький, . . огуцький, . . олошин // кр їнське олісся : вчор , сьогодні, з втр : зб. н ук. пр ць. - уцьк: дстир'я, 1998. - . 105-107.

6. порные р зрезы и кр евые обр зов ния м териковых оледенений з п дной ч сти кр ины. VI сесоюзному совещ нию по изучению кр евых обр зов ний м терикових оледенений / [ . . огуцкий, . . еличко, . . . еренчук и др.]. - иев : н-т геол. н ук , 1980. - 52 с. - ( репринт / , н-т геол. н ук; 80-17).

7. ись . . еоморфологія / . . ись. - ьвів : ид-во ьвів. ун-ту, 1962. $224 \mathrm{c}$.

8. Fedorowicz S. Loess-paleosol sequence at Korshiv (Ukraine): Chronology based on complementary and parallel dating (TL, OSL), and litho-pedosedimentary analyses / S. Fedorowicz, M. Łanczont, A. Bogucki [et al.] // Quaternary International. - 2013. Vol. 296. - P. 117-130.

9. Kusiak J. New exposure of loess deposits in Boyanychi (Ukraine) - Results of thermoluminescence analyses / J. Kusiak, M. Łanczont, A. Bogucki // Geochronometria. - 2012. Vol. 39 (1). - P. 84-100. 


\title{
ENGINEERING-GEOLOGICAL CHARACTERISTIC OF THE ROCKS OF THE LOESS-SOIL SERIES FROM THE KEY SECTION BOYANYCHI (VOLHYNIAN UPLAND)
}

\author{
Andriy Bogucki, Petro Voloshyn \\ Ivan Franko National University of Lviv, \\ . Doroshenko Str., 41, UA - 79000 Lviv, Ukraine
}

Boyanychi key section is one of the most complete, most famous and best studied sections of periglacial loess-soil series of Volhyn-Podillia. An almost complete history of the formation of rocks for the last 600000 years is represented here. There is total thickness of loess-soil series approximately is 25 meters in this section. This key section is stratotype of Sokal fossil soil. Pseudomorphs after the structures of cellular ice of Boyanychi palaeocryogenesis stage were allocated here for the first time for Volhyn-Podillia and individual significance of this stage was substantiated as one of the most ancient in the Pleistocene. Boyanychi key section was studied by the use of practically all methods which apply for the investigation of Pleistocene deposits (in particular, micromorphological, palaeocryogenic, palaeomagnetic, engineering-geological, palaeontological, methods of absolute dating of deposits etc.). Detailed description of the section and the results of engineering-geological studies of rocks of all selected loess and palaeosoil horizons were done. Individual properties of selected stratigraphic horizons and their dependence on the paleogeographic conditions of sedimentation were displayed.

Key words: loesses, fossil soils, palaeogeographical conditions, palaeocryogenesis, engineeringgeological features, subsidence, Volhynian Upland. 